\title{
DETERMINATION OF MASS, VOLUME AND DENSITY FOR DIFFERENT VARIETIES OF OLIVE FRUITS \\ Matouk A.M. ${ }^{(1)} ;$ S. El-Khawaga ${ }^{(2)} ;$ T.R. Owies $S^{(2)}$ and M.M. EL-Kholy(2) \\ 1- Agric. Eng. Dept. Fac. of Agric., Mansoura Univ. \\ 2- Agric. Eng., Res. Institute Dokki. Giza.
}

\begin{abstract}
An experimental work was conducted to determine mass, volume and density of different olive varieties. the selected varieties included oil producing varieties (Kronaki, Coratina and Arab queen) and duel purpose varieties (Watiken, Picual and Manzanillo). The results show that, the mass of olive fruits was ranged from (1.17 to $3.34 \mathrm{~g}$ ) and from (3.349 to $6.19 \mathrm{~g}$ ) for the oil producing and duel purpose varieties respectively. Wile it was ranged from $(0.25$ to $0.617 \mathrm{~g})$ and from $(0.635$ to $0.756 \mathrm{~g})$ for their pits.

The fruits measured volume was ranged from $\left(1.085\right.$ to $\left.3.165 \mathrm{~cm}^{3}\right)$ for the oil producing varieties and from (3.09 to $\left.4.195 \mathrm{~cm}^{3}\right)$ for the duel purpose varieties. On the same time the measured and the calculated fruit volumes of different studied varieties could be related and expressed as $\mathrm{V}$ act $=0.524 \mathrm{LD}^{2}$. The fruit real density was ranged from $\left(0.934\right.$ to $\left.1.113 \mathrm{~g} / \mathrm{cm}^{3}\right)$ and from $\left(0.994\right.$ to $\left.1.109 \mathrm{~g} / \mathrm{cm}^{3}\right)$ for oil producing and duel purpose varieties. While the corresponding values of bulk density was ranged from $\left(579.268\right.$ to $\left.626.560 \mathrm{~kg} / \mathrm{m}^{3}\right)$ and from $\left(600.79\right.$ to $\left.642.767 \mathrm{~kg} / \mathrm{m}^{3}\right)$ respectively.
\end{abstract}

\section{INTRODUCTION}

It is essential to understand the physical low governing the response of agricultural biological materials, so that, processing and handling machines can be designed for maximum efficiency and highest quality of the end product, (El-Sahrigi, 1997).

Shape, size, mass, volume, surface area, density, and porosity are some of the physical characteristics which are important in many problems associated with design of specific machine or analysis of the behavior of the product in handling and processing operations, (Mohsenien, 1984).

Buyanov and Voronyuk, (1985) reported that, the density is the mass per unit volume of agricultural produce. It is called bulk density when considering friable or semi friable produce and when contained in a vessel not subject to any external load except its own mass. The volume mass (bulk density) is calculated by the following formula:

Where:

$$
\rho=q / v
$$

$$
\begin{aligned}
& \rho=\text { density of produce }, \mathrm{kg} / \mathrm{m}^{3} \\
& \mathrm{q}=\text { mass of sample, } \mathrm{kg} \\
& \mathrm{V}=\text { volume occupied by it, } \mathrm{m}^{3}
\end{aligned}
$$

Matouk et. al., (2005) investigated the fruit mass, bulk density, real density and porosity of five different varieties of olive fruits. They found that, the fruit mass, bulk density, real density and porosity was ranged from (0.49 to $9.00 \mathrm{~g}),\left(627.91\right.$ to $\left.713.58 \mathrm{~kg} / \mathrm{m}^{3}\right)$ and $(40.6$ to $43.88 \%)$ respectively. 
El-Sayd, (2004) investigated the principal dimensions, mass and true density of three different olive varieties (Manzanillo, Egizy and Bicual). The results show a significant difference between the studied varieties. He also mentioned that the true density is dependent upon the olive variety and ranged from 1.03 to $1.09 \mathrm{~g} / \mathrm{cm}^{3}$.

Ibrahim, (1992) reported that any processed materials vary considerably in their physical properties such as size, shape, density, volume, specific gravity, porosity and surface texture. These characteristics are very important in many problems associated with design or developing a specific machine.

Chen and Sun, (1991) reported that, the relationship between density and quality of agricultural products has been recognized for more than a century. The density of many fruits and vegetables increase with maturity. On the other hand, certain types of damage and defects tend to reduce the density of the product.

The present study aims to determine some physical characteristics of different varieties of oil producing and duel purpose olive varieties. These characteristics included mass, volume and density of the investigated varieties.

\section{MATERIALS AND TEST PROCEDURE}

\section{Materials:}

The selected varieties of the present study represent two different categories of olive fruits. The first category included the oil producing varieties (Kronaki, Coratina and Arab queen) and the second category included the duel purpose varieties (Watiken, Picual and Manzanillo).

The collected samples of each variety were kept in perforated plastic boxes in a refrigerator adjusted at $4{ }^{\circ} \mathrm{C} \pm 1$. The average moisture content of olive fruits were ranged from 58 to $65 \%$ (w.b.) as determined for the crushed fruits by the oven method at $105{ }^{\circ} \mathrm{C}$ for 24 hours. The measured physical properties for the investigated fruits included, mass of fruits and their pits, fruit volume, and real and bulk densities.

\section{Fruit mass and volume:}

The mass of fruit and its pit was determined using a digital balance with accuracy of $0.001 \mathrm{~g}$. While the volume was measured by immersing each fruit in $20 \mathrm{~mm}$ graduated cylindrical beaker filled with toluene for $5 \mathrm{~min}$. the displaced toluene or the increase in toluene volume was determined and considered as the accurate volume of individual fruit.

The theoretical volume of fruit was determined according to (Mohsenin, 1984) as follows:

Where:

$$
V_{\text {th }}=\pi / 6 . L . D_{f^{2}}
$$

\footnotetext{
$V_{\mathrm{th}}=$ theoretical volume of fruit, $\mathrm{mm}^{3}$

$\mathrm{L}=$ length of fruit, $\mathrm{mm}$

$D_{f}=$ diameter of fruit, $\mathrm{mm}$
} 
Real and bulk densities of fruits:

Real density of olive fruits was measured and calculated as follows:

Where:

$$
\rho_{r}=m_{e} / V_{\text {meas }}
$$

$\rho_{r}=$ real density of the individual fruit, $\mathrm{g} / \mathrm{cm}^{3}$

$\mathrm{m}_{\mathrm{e}}=$ mass of olive fruit, $\mathrm{g}$

$\mathrm{V}_{\text {meas }}=$ measured volume of the individual fruit, $\mathrm{cm}^{3}$

While, the bulk density of olive fruits was measured by weighing a certain amount of olive fruits filled inside a wooden box with known volume and by dividing the mass of olive fruit by the box volume the bulk density could be calculated using the following relationship:

Where:

$$
\rho_{B}=m_{b} / V_{b}
$$

$$
\begin{aligned}
& \rho B=\text { bulk density of olive fruit, } \mathrm{kg} / \mathrm{m}^{3} \\
& \mathrm{~m}_{\mathrm{b}}=\text { mass of olive bulk, } \mathrm{kg} \\
& V_{b}=\text { calculated volume of olive bulk, } \mathrm{m}^{3}
\end{aligned}
$$

\section{RESULTS AND DISCUSSION}

\section{Mass of fruit and their pit:}

Figs (1) and (2) illustrate the variation in mass of fruits and their pit for different studied oil producing and duel purpose olive varieties.

As shown in Fig. (1), the mass of fruits for the oil producing varieties, was ranged from (1.17 to $3.349 \mathrm{~g})$. The frequency distribution curves also show that, variety Coratina Arish has much larger base and much dispersion in comparison with other varieties, and variety Coratina Arish recorded the highest (C.V.) value of $24.866 \%$ while variety Coratina Sahrawy recorded the lowest values of $13.768 \%$.

However, as illustrated in Fig. (2), variety Coratina Sahrawy recorded the highest pit mass $(0.617 \mathrm{~g})$ and variety Kronaki Sahrawy recorded the lowest value of $(0.25 \mathrm{~g})$. The frequency distribution curves show that, variety Coratina Arish recorded the highest dispersions and variety Coratina Sahrawy was the lowest. Also, variety Coratina Arish recorded the highest (C.V.) of $28.834 \%$ while variety Coratina Sahrawy recorded the lowest value of $14.22 \%$.

For duel purpose varieties, the fruit mass was ranged from (3.349 $\mathrm{g}$ to $6.199 \mathrm{~g}$ ) and the frequency distribution curves show that, variety Picual Arish recorded the highest dispersions followed by varieties Picual Sahrawy and Watiken Siwa while variety Manzanillo Sahrawy was the lowest. The (C.V.) values for the investigated duel purpose varieties sorted from the highest to the lowest such as 22.194, 21.542, 21.504, 18.115, 15.986 and $12.179 \%$ for varieties Picual Sahrawy, Watiken Siwa, Watiken Sahrawy, Manzanillo Arish and Manzanillo Sahrawy respectively.

Meanwhile, as shown in Fig (2), the pit mass of the duel purpose varieties was ranged (from $0.635 \mathrm{~g}$ to $0.756 \mathrm{~g}$ ) and variety Watiken Siwa recorded the highest dispersions followed by varieties Picual Sahrawy and Watiken Siwa, while variety Manzanillo Sahrawy recorded the lowest dispersions. On the other hand, the obtained (C.V.) values for the duel purpose varieties were ranged (from $13.798 \%$ to $27.051 \%$ ). 
Matouk A.M. et al.

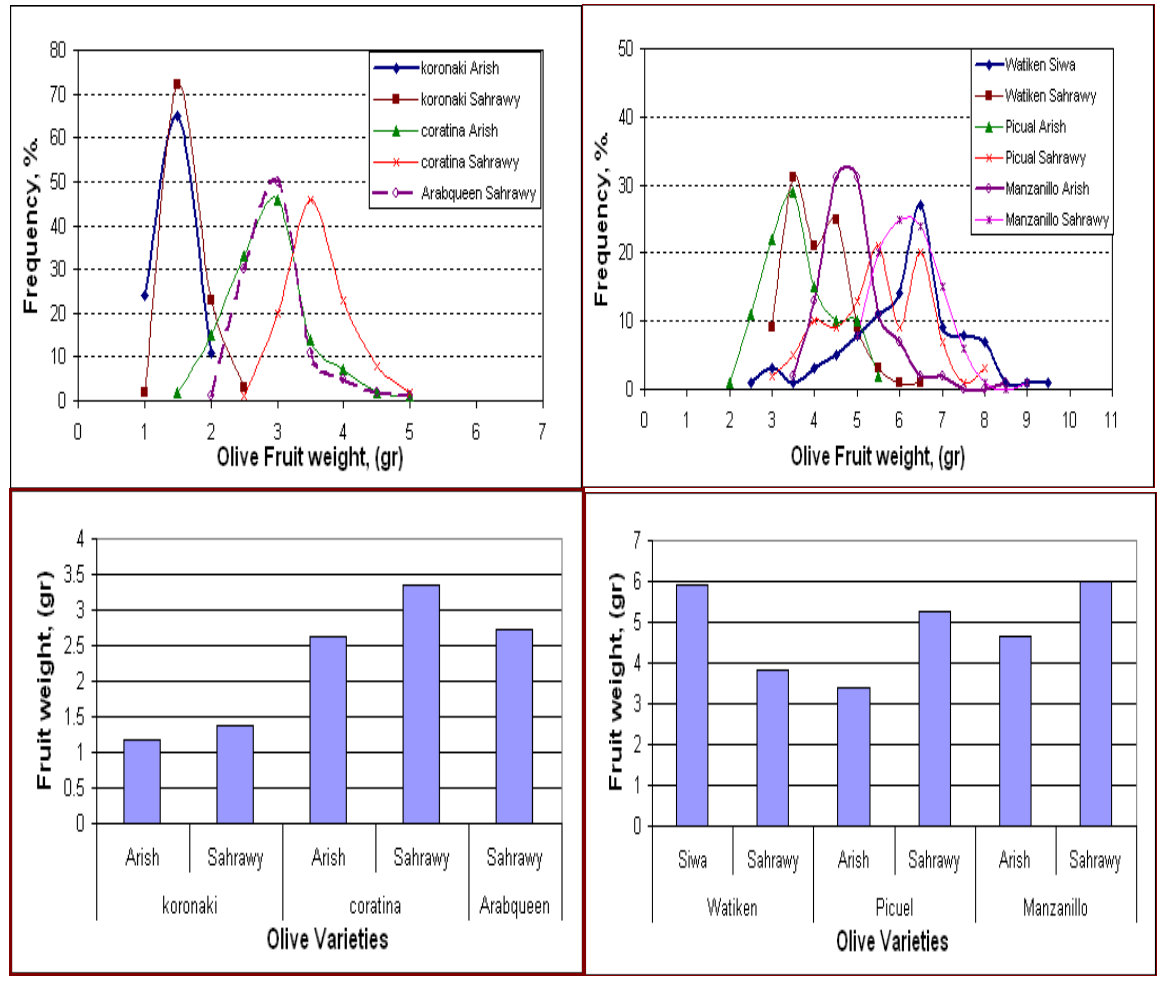

Oil varieties

Duel varieties

Fig. (1): Normal distribution curves and histograms for olive fruit mass of both oil producing and duel purpose varieties.

\section{Fruit volume (measured and calculated):}

Measured volume $\left(\mathrm{V}_{\text {meas }}\right)$ :

Fig. (3) presents the variations in the measured volume of both oil producing and duel purpose olive varieties.

As shown in the figure, the maximum fruit volume for the oil producing varieties was $3.165 \mathrm{~cm}^{3}$ for variety Coratina Sahrawy and the minimum value was $1.085 \mathrm{~cm}^{3}$ for variety Kronaki Arish.

The frequency distribution curves show that, variety Coratina Arish recorded the highest dispersions while varieties Arab queen Sahrawy was the lowest. The obtained (C.V.) values of the oil producing varieties could be sorted from the highest to the lowest such as 26.512, 24.297, 21.530, 15.202 and $15.072 \%$ for varieties Coratina Arish, Kronaki Sahrawy, Kronaki Arish, Arab queen and Coratina Sahrawy respectively.

For the duel purpose varieties, as shown in Fig. (3), variety Watiken Siwa recorded the highest measured volume of $5.94 \mathrm{~cm}^{3}$ followed by varieties Picual Sahrawy, Manzanillo Arish, Watiken Sahrawy and Picual Arish which recorded a values of $4.915,4.593,3.565$ and $3.09 \mathrm{~cm}^{3}$ respectively. 


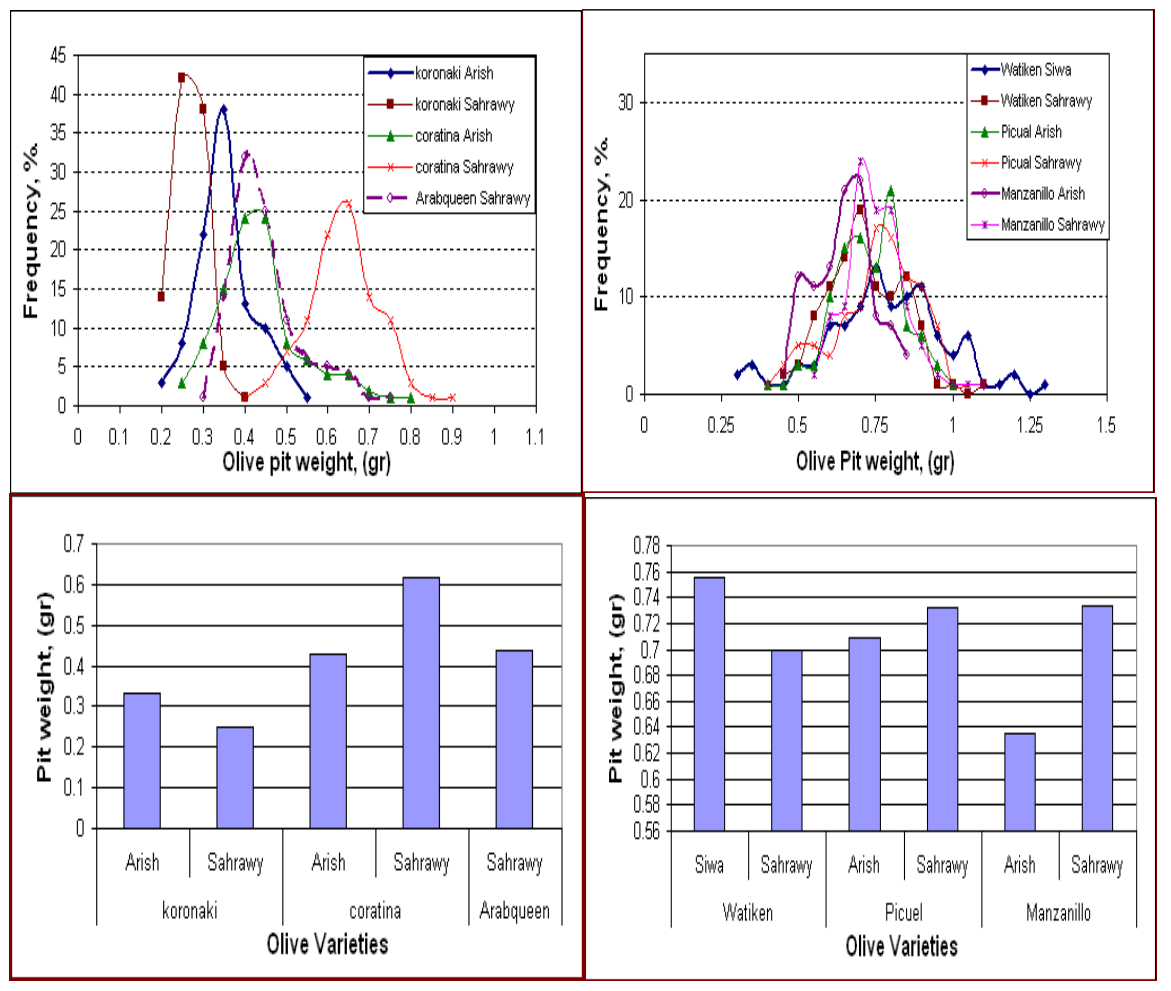

Oil varieties

Duel varieties

Fig. (2): Normal distribution curves and histograms for olive pit mass of both oil producing varieties and duel purpose varieties.

On the same time, the frequency distribution curves show that variety Picual Arish recorded the highest dispersions while variety Manzanillo Sahrawy was the lowest. Also, the (C.V.) values for the duel purpose varieties were sorted from the highest to the lowest such as 22.91, 20.32, $18.341,15.96$ and $11.904 \%$ for varieties Picual Sahrawy, Watiken Siwa, Watiken Sahrawy, Manzanillo Arish and Manzanillo Sahrawy, respectively.

Fruit calculated volume $\left(\mathrm{V}_{\text {cal }}\right)$ :

As previously mentioned, the calculated fruit volume $\left(V_{\text {cal }}\right)$ of the oil producing and the duel purpose varieties was determined using the equation:

$$
V_{c a l}=\frac{\pi}{6 . L D^{2}}
$$

On the same time the correlation between the measured and the calculated fruit volume was fitted using linear regression analysis and it was found to be following the relationship:

$$
\mathbf{y}=\mathbf{b} \mathbf{x}
$$

Where:

$\mathrm{x}=$ the calculated volume $\left(\mathrm{V}_{\text {cal }}\right), \mathrm{cm}^{3}$

$\mathrm{y}=$ the measured volume $\left(\mathrm{V}_{\text {meas }}\right), \mathrm{cm}^{3}$

$\mathrm{b}=$ constant (varied for different varieties) 


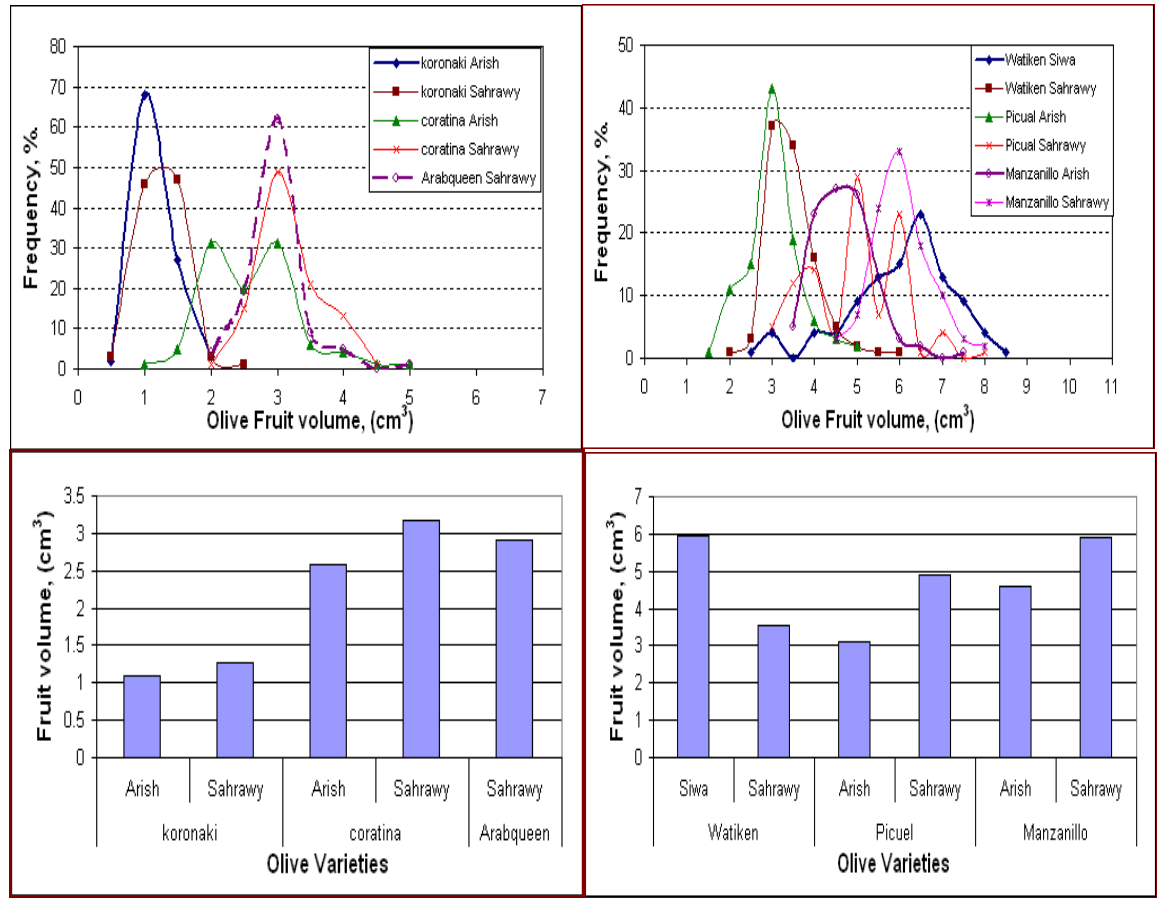

Oil varieties

Duel varieties

Fig. (3): Normal distribution curves and histograms for olive fruit volume of both oil producing and duel purpose varieties.

The equations represent different investigated oil producing and duel purpose varieties are shown in Table (1). As shown in the table, the values of constant (b) of all equations were very close. So that, the relationship between the measured and the calculated fruit volume of different varieties could be expressed in a general relationship as follows:

$\mathrm{V}_{\mathrm{act}}=0.524 \mathrm{~L} \mathrm{D}^{2}$

Where the value (0.524) was the average of the constant (b) values.

Table (1): Relationship between the actual and the calculated fruit volume.

\begin{tabular}{|c|c|c|}
\hline Olive Varieties & Equations & $\mathbf{R}^{2}$ \\
\hline \multicolumn{3}{|l|}{ 1-Oil Producina Varieties: } \\
\hline Kronaki Arish & $V_{\text {act }}=0.534 L^{2}$ & 0.837 \\
\hline Kronaki Sahrawy & $\mathrm{V}_{\mathrm{act}}=0.487 \mathrm{LD}^{2}$ & 0.826 \\
\hline Coratina Arish & $\mathrm{V}_{\mathrm{act}}=0.533 \mathrm{LD}^{2}$ & 0.931 \\
\hline Coratina Sahrawy & $\mathrm{V}_{\mathrm{act}}=0.521 \mathrm{LD}^{2}$ & 0.877 \\
\hline Arab queen Sahrawy & $\mathrm{V}_{\mathrm{act}}=0.543 \mathrm{LD}^{2}$ & 0.848 \\
\hline \multicolumn{3}{|l|}{ 2-Duel Purpose Varieties: } \\
\hline Watiken Siwa & $\mathrm{V}_{\mathrm{act}}=0.552 \mathrm{LD}^{2}$ & 0.936 \\
\hline Watiken Sahrawy & $\mathrm{V}_{\mathrm{act}}=0.537 \mathrm{LD}^{2}$ & 0.869 \\
\hline Picual Arish & $\mathrm{V}_{\mathrm{act}}=0.497 \mathrm{LD}^{2}$ & 0.934 \\
\hline Picual Sahrawy & $\mathrm{V}_{\mathrm{act}}=0.525 \mathrm{LD}^{2}$ & 0.927 \\
\hline Manzanillo Arish & $\mathrm{V}_{\mathrm{act}}=0.509 \mathrm{LD}^{2}$ & 0.849 \\
\hline Manzanillo Sahrawy & $\mathrm{V}_{\mathrm{act}}=0.527 \mathrm{LD}^{2}$ & 0.918 \\
\hline 3- General equation for all varieties & $\mathrm{V}_{\mathrm{act}}=0.524 \mathrm{LD}^{2}$ & 0.915 \\
\hline
\end{tabular}




\section{Fruit real density:}

Fig. (4) illustrates the variation in real density of the investigated oil producing and duel purpose varieties.

For oil producing varieties, Fig. (4) shows that, variety Kronaki Sahrawy recorded the highest true density of $1.113 \mathrm{~g} / \mathrm{cm}^{3}$ followed by varieties Kronaki Arish, Coratina Sahrawy, Coratina Arish and Arab queen Sahrawy which recorded values of $1.088,1.063,1.024$ and $0.934 \mathrm{~g} / \mathrm{cm}^{3}$ respectively.

On the same time the frequency distribution curves show that, variety Kronaki Sahrawy has the highest dispersions while variety Coratina Sahrawy was the lowest. The obtained (C.V.) values for the oil producing varieties could be sorted from the highest to the lowest such as 13.173, 10.848, $10.753,7.772$ and $7.288 \%$ for varieties Kronaki Sahrawy, Kronaki Arish, Coratina Arish, Arab queen Sahrawy and Coratina Sahrawy respectively.

For duel purpose varieties, Fig. (4) also, shows that, the true density of different studied varieties was varied from 0.994 to $1.109 \mathrm{~g} / \mathrm{cm}^{3}$. On the same time variety Watiken Sahrawy recorded the highest dispersions while variety Manzanillo Sahrawy was the lowest. The obtained (C.V.) values for the duel purpose varieties were sorted from the highest to the lowest such as 9.807, $9.258,7.493,6.656,6.633$ and $4.218 \%$ for varieties Watiken Sahrawy, Picual Arish, Picual Sahrawy and Manzanillo Sahrawy, respectively.
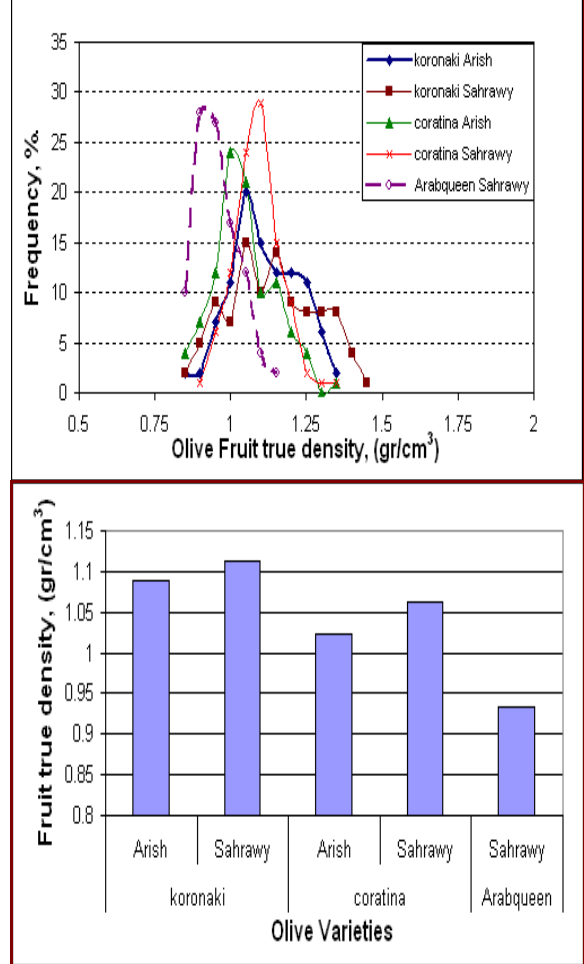

Oil varieties
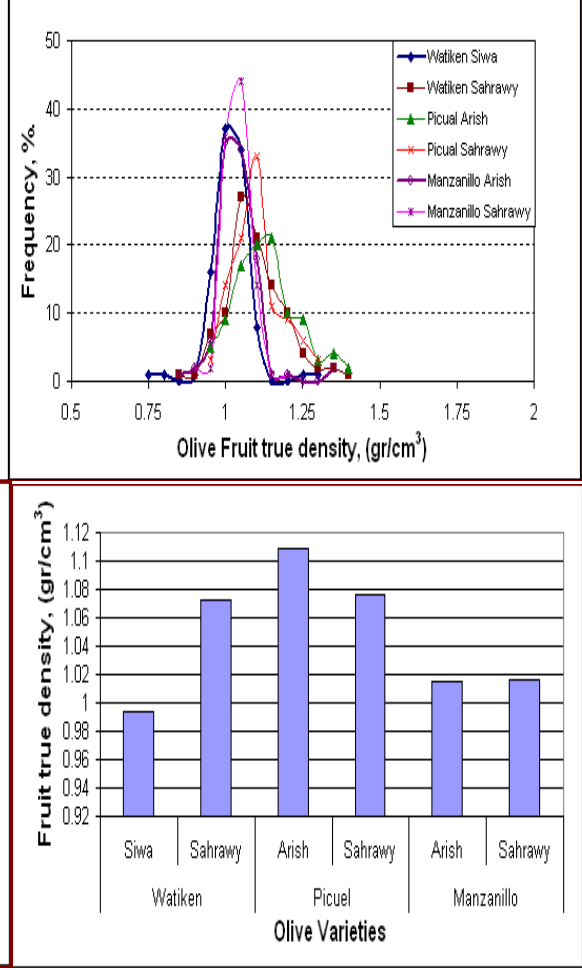

Duel varieties

Fig. (4): Normal distribution curves and histograms for mean values of true density of both oil producing and duel purpose varieties. 


\section{Fruits bulk density:}

Bulk density of different oil producing and duel purpose olive varieties are presented in Fig. (5). For oil producing varieties, variety Kronaki Arish recorded the highest value of bulk density $\left(626.560 \mathrm{~kg} / \mathrm{m}^{3}\right)$ followed by varieties Coratina Sahrawy, Kronaki Sahrawy, Coratina Arish and Arab queen which recorded values of $617.886,606.530,598.868$ and $579.268 \mathrm{~kg} / \mathrm{m}^{3}$ respectively.

While, for the duel purpose varieties, Fig. (5) shows that, variety Watiken Siwa recorded the highest bulk density of $642.767 \mathrm{~kg} / \mathrm{m}^{3}$ followed by varieties Manzanillo Arish, Picual Sahrawy, Picual Arish, Watiken Sahrawy and Manzanillo Sahrawy which recorded values of $623.282,621.138,615.648$, 602.033 and $000.794 \mathrm{~kg} / \mathrm{m}^{3}$, respectively.



Oil varieties

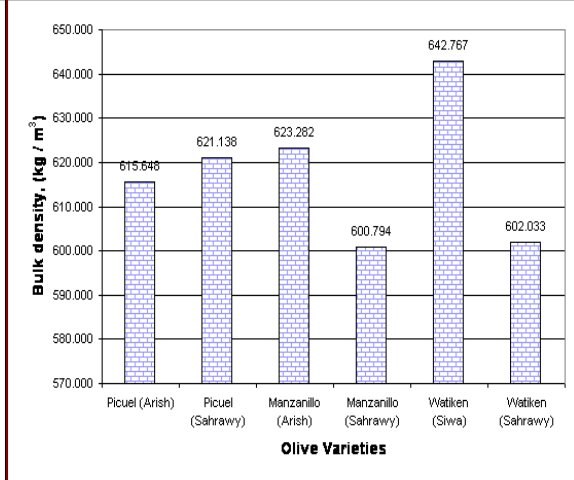

Duel varieties

Fig. (5): Histograms for mean values of olive fruit bulk density for both oil producing and duel purpose varieties.

\section{CONCLUSION}

1- Mass of olive fruits and their pits was higher for the duel purpose varieties in comparison with the oil producing varieties.

2- The fruits measured values was higher for the duel purpose varieties and in comparison with the oil producing varieties and it was related with the calculated volume using the following equation:

$$
\mathrm{V}_{\mathrm{act}}=0.524 \mathrm{LD}^{2} \text {. }
$$

3- The fruits real density was ranged from $\left(0.934\right.$ to $\left.1.113 \mathrm{~g} / \mathrm{cm}^{3}\right)$ and from $\left(0.994\right.$ to $\left.1.109 \mathrm{~g} / \mathrm{cm}^{3}\right)$ for oil producing and duel purpose varieties, respectively. While the bulk density was ranged from $(579.268$ to 626.560 $\left.\mathrm{kg} / \mathrm{m}^{3}\right)$ for the oil producing variety and from $\left(600.79\right.$ to $\left.42.767 \mathrm{~kg} / \mathrm{m}^{3}\right)$ for the duel purpose varieties. 


\section{REFERENCES}

Buyanov, A.I. and B.A. Voronyuk, (1985). Physical and mechanical properties of plants fertilizers and soils. Amerind pub. Co., PVT, LTD, New Delhi, Bombay, Calcutta, New York.

Chen, P. and Z. Sun, (1991). A review of non-destructive methods for quality evaluation and sorting. Agric. Eng. Res.: ISSN 0021-8634. Vol. 48-50.

El-Sahrigi, A.F., (1997). Fundamental of food processing engineering. Text Book Acad. Library. Egypt.

El-Sayed S. El. M., (2004). Mechanization of grading olive as one of the most important desert crops. Un published M.Sc. Thesis Agric. Eng. Dept. Fac. of Agric. Mansoura Univ., Egypt.

Ibrahim A.M., (1992). Design an apparatus suitable for winnowing and separating wheat products from stationery threshers. Un published M.Sc. Thesis Fac. of Agric. Alexandria Univ., Egypt.

Matouk A.M., A.E. Abu El-Maged, A.S. Hamam and T.R. Owies, (2005). Physical properties for some Egyptian varieties of olive and their relation to olive conveying auger design. Egypt J. Agric. Res., 83(2):1005-1029.

Mohsenien, N.N., (1984). Physical properties of plant and animal materials. New York. Gordon and Breach Science Publishers.

$$
\begin{aligned}
& \text { إين الكتلة، الحجم، الكثافة لأصناف الزيتون المختلفة }
\end{aligned}
$$

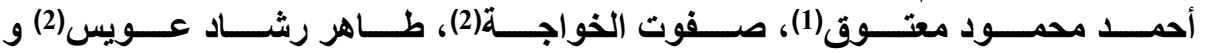

$$
\begin{aligned}
& \text { محمد مصطفي الذولي الخدئ (2) }
\end{aligned}
$$

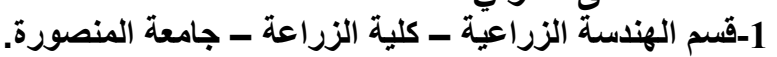

$$
\begin{aligned}
& \text { 2-معهد بحوث الهندة الزراعية ـ دقي - جيزة. }
\end{aligned}
$$

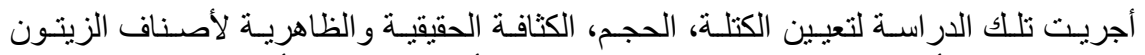

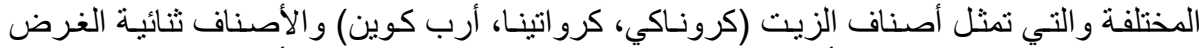

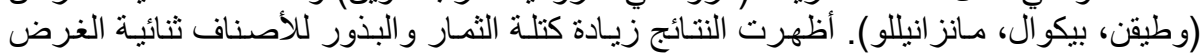



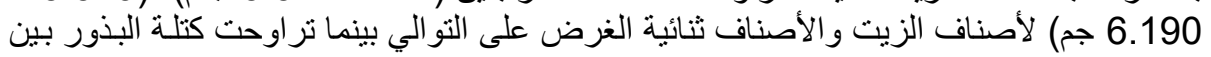

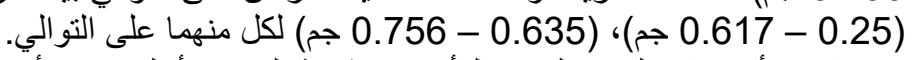

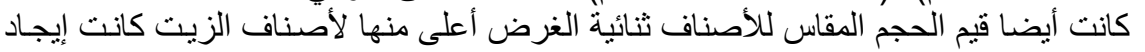

$$
\begin{aligned}
& \text { علاقة تربط بين الحجم المقاس و الحجم المحسوب للثمار في الصورة الصناف: } \\
& \mathrm{V}_{\mathrm{act}}=0.524 \mathrm{LD}^{2}
\end{aligned}
$$

